\title{
Semantic Framing of Nationalism in the National Anthems of Egypt and England: A Cognitive Study
}

\author{
Esra' Mustafa \\ Faculty of Al-Alsun, Ain Shams University, Egypt
}

Copyright (C) 2015 by authors, all rights reserved. Authors agree that this article remains permanently open access under the terms of the Creative Commons Attribution License 4.0 International License

\begin{abstract}
Every human experience can be conceptually represented in terms of semantic frames. Frames set the major cognitive general aspects of any concept, as well as the contextual variants of such a concept. Being a universal concept, NATIONALISM is central to the human cognition. However, neither political science, nor dictionary makers consent upon its definition. This study uses semantic frame in understanding NATIONALISM as expressed in English and Egyptian national anthems. It aims at contrasting these anthems in order to render the basic constituents of the frame. Despite the different scenes represented in each anthem's frame, NATIONALISM typically actives the frame of people, place, power and principles. The eight national anthems, subject to the analysis, along with a number of political science definitions of NATIONALISM can be contained under this general conceptual frame. The frame interacts with the basics of sociology. Being developed over time and place, NATIONALISM still summons the same frame of a society of people gathered in one place sharing the same principles and governed by the same power.
\end{abstract}

Keywords Semantic Frames, Attributes, Values, Structural Invariants, Constraints, Nationalism, National Anthems.

\section{Introduction}

NATIONALISM is an interdisciplinary notion; it has sociological, psychological, political, and historical aspects. However, there is not a conventional definition of it, not even a literally linguistic one. Revealing different dimensions of the concept, studies define NATIONALISM pertaining on shared ideologies, behaviors, beliefs devotion, language, territory, rights and duties [1]. It is also identified as 'an imagined political community' in which people do not know each other, but conceptually share the 'communion' image, Anderson and Smith [2,3] differently describes it as a group of people seeking the right of self-determination and unity.

Linguistic definitions of NATIONALISM exhibit various perspectives too. English dictionaries; Merriam-Webster[4], Longman[5] and Oxford[6] propose different definitions such as being loyal, proud of a country, believing in the country's superiority, advocating a country's independence, having people with shared culture and history calling for forming a nation, among many other meanings. Classic Arabic dictionaries; Lisan Al-arab[7], among others, do not include the word 'الوطنية/NATIONALISM', yet its linguistic root 'وطن/homeland' conventionally means a 'place of stay'. Modern Arabic dictionaries; Al-ghani, ArRa'ed and Al-logha Al-Arabia Al-moa'sera[7], define /al-wattania" as being attached to a homeland, and sincerely love and sacrifice for it.

Billig[8] links NATIONALISM to language, exploring it as expressed in naturally-occurring conversations; as it is an 'everyday phenomenon'. The study reveals that respondents vary in their ideologies about nationalism; some speak about the country in terms of its unity, while others speak of it in terms of its diversity. The various, usually unrelated, definitions are an attempt to cover all the possible contextual senses of the term, but they fail to establish a conventional basis of it.

Being purely cognitive, semantic frames can be used to reach a general empirical definition of NATIONALISM. A semantic frame starts with scenes, whether perceptual or linguistic, and then conceptually analyzes them to reach the ultimate shared cognition collocated with them. Frames are introduced to move beyond the surface level of language, and detect the general cognitive characteristics of a notion. A frame-based definition typically captures the essential aspects of a notion, and is converged with other empirical sciences.

\subsection{Review of Literature}

Evans \& Green [9] suggest that the limitedness and de-contextualization of the dictionary meaning urged the need for a comprehensive empirical approach addressing the encyclopedic nature of meaning. Such an encyclopedic view of meaning reflects the language-experience dualism. Fillmore's frame semantics is an empirical cognitive 
attempt to overcome the shortcomings of the traditional purely linguistic theories of meaning. It starts from the hypothesis that a word's meaning is always context-dependant. That is to say, it totally rejects the semantic/pragmatic distinction and relies on the worldly knowledge as the foundation of meaning.

The cognitive sense of the word frame is first used by Fillmore [10]. He proposes it as a solution to the problems of traditional checklist theories. Introducing a new term, Fillmore cognitively defines frames as linguistic system reflecting certain experience; 'scene'. That is to say, meaning is completely dependent on human experience. The then-under-formation theory has been very generally applied to the language learning scene in which a child learns the linguistic unit describing the whole situation; then he tends to acquire the linguistic labels of the parts constituting the frame. With the course of time a child is able to link the similar components of different scenes to each other.

Two years later, Fillmore[11] has linguistically crystallized the semantic frames theory providing the first primitive frame of the verb 'buy'. He proves that the verb 'buy' typically summons the 'buyer', 'seller', 'goods' and 'money' structure. He marks this structure as the broad general level of the frame. Such level reveals the vital elements, 'aspects', of the frame. A frame has another level which is dynamic and perspective. This perspective level changes according to the collocated items, 'types', with the 'aspects'.

Moving from the general conceptual level to a more linguistic-based application of the theory, Fillmore \& Atkins [12] introduce a corpus-based frame of the word 'risk'. The frame accounts for all the nouns, verbs, adverbs and adjectives collocating with the 'risk'. Thus, the different senses of the word are concluded. Conceptually analyzing the frame, two cognitive notions are highlighted; 'chance' and 'harm'. Moreover, he clarifies the sub-frames activated by the major frame of 'risk'; 'risk taking' and 'risk running'. The frames are divided into categories, including 'victim', 'risking situation' and 'valued object'. The associated syntactic structures of each category are mapped in the frame.

Petruck [13] conducts a comprehensive study of the 'body' frame in Hebrew. The study combined both the literal and metaphoric senses of body parts. It conceptually widens the scope of frame beyond the surface word level. The study analyzed the concept of body with its related senses and linguistic structures. The researcher traces the "extensions" of the body parts terms to investigate the interaction between the body frame and other metaphoric frames. The basic frame of 'body' and all the correlationally activated frames are interpreted within the same physical experience of the human body.

Fillmore and Baker [14] link frames to first language (L1) acquisition. L1 acquisition is derived from physical experience. A child gains the linguistic knowledge contextually. As an illustration, when a child is exposed to a physical pain scene, he learns linguistic expressions such as "ouch", "it hurts", "headache", etc. Then he extends the frame of pain to include other linguistic realizations and links them to all body parts. Finally, humans, at a certain point, become able to develop this experience-based linguistic knowledge and broaden the frame at a more abstract level. That is why, metaphors such as "pain is a motivating force" can be contained and understood within the pain frame.

Recently frame semantics theory has been applied computationally. Xie et al[15] use semantic frames to predict stock price movement. Their paper argues for the ability of frame semantics to provide better quality information and prediction of the stock market than the bag-of-words approach, which depends mainly on meaning distribution among the content words of a text. The researchers depend on events frames and conceptual relation evoked by the lexical items in financial news to "predict change in stock price". They automatically detect the linguistic similarities in financial news, marking the different/similar frames they evoke. They concentrate on the valence descriptions of the used verbs and how the companies are situated within each frame. Their promising results reveal the importance of frame semantics in enhancing stock predictions. Moreover, a whole computational model of price stock prediction can be build depending on the semantic fields activated by news pieces.

Lo \& Wu [16] exploit frame semantics to develop machine translation. They adopt the principle that a successful translation has to be a useful one; revealing the event's key aspects to the reader, namely "who did what to whom? When? Where? And why?" In other words, revealing the scene/frame of the original text. It assesses the ability of CAT tools to detect these major meaning aspects by manually "annotate[ing] semantic frames" of the translation and the source. Then, test the machine system of the new tool "MEANT" to evoke the same manually evoked frames. That is to say, a useful translation has to evoke the same frames evoked by the original.

\subsection{Study Objectives}

This study depends on the semantic frames theory to analyze the concept of NATIONALISM in Egyptian and English national anthems. It aims at:

First, identifying the core attributes of each frame of a given national anthem and the values of these attributes, along with the structural invariant correlating them to each other; second, highlighting the shared elements, if any, among the eight national anthems, as well as contrasting the major differences; third, determining whether the different political, social, military and cultural English and Egyptian scenes are reflected in the frames; and finally, rendering a cognitively-based definition of NATIONALISM as presented in the eight national anthems.

\subsection{Significance of the Study}


Given the sufficient magnitude of the national anthems to saturate the core of nationalism, this cross-cultural study fathoms the crux of the recruited anthems in England and Egypt. The selection of the occidental and oriental countries is statistically ushering the results a step forward toward universality. The findings, however, help the reader and the researcher conceptualize something that used to be dimly-lit pages of sociology, psychology and anthropology.

\subsection{Sources of Data}

This study frames NATIONALISM as represented in English and Egyptian national anthems. It recruits the four interchangeable English national anthems and the four Egyptian national anthems used from 1923 hitherto. The data is extracted from three websites; the national anthems dedicated website, http://www.nationalanthems.info/ [17], the official Egyptian Website http://www.sis.gov.eg/Ar/Templates/Categories/tmpLand.as px?CatID $=10$ [18] and the official website of the British monarchy

http://www.royal.gov.uk/MonarchUK/Symbols/NationalAn them.aspx [19].

\section{Materials and Methods}

Content words are extracted from each anthem, and then semantically related words are grouped together. The most comprehensive word in each group is labeled as attribute, the rest of words, which can be included under it, are tagged as its values. Occasionally two or more attributes have values in common. After defining the core attributes and values of a frame, the whole anthem is used in order to detect the conceptual relations, structural invariants, between the core attributes. Structural invariants are determined according to the linguistic context within which the attributes occur. Applying the same process values constraints are identified. However, additional links between an attribute and another attribute's value have emerged. They are added to the frame as linguistically contextual relations.

\section{Theoretical Background}

\subsection{Semantic Frames}

'Semantic frames' is a cognitive linguistic theory 'relates linguistic semantics to encyclopedic or real-world knowledge', Richards \& Schmidt [20]. Fillmore has introduced it as an 'approach to cognitive lexical semantics... to uncover the properties of the structured inventory of knowledge associated with words, and to consider what consequences the properties of this knowledge system might have for a model of semantics'[21]. Fillmore [22], the founder of the theory, describes a frame as 'any system of concepts related in such a way that to understand any one of them you have to understand the whole structure in which it fits; when one of the things in such a structure is introduced into a text, or into a conversation, all of the others are automatically made available'.

The semantic frames theory is deeply rooted in cognitive psychology. It is based on the figure-ground gestalt trend. Any experience in the physical world can be segmented in terms of figure and ground. Figure is the predominant constituent in the figure-ground system; it is placed within certain surroundings; ground, Evans [21]. Applying it to language, Fillmore [13] expounds that the linguistic unit employed by a user is the figure, while the human experience behind it is the ground. Human experience here refers to the encyclopedic knowledge associated with this linguistic unit, 'frame'.

Being introduced for the first time, the theory used to distinguish the concept of 'frame' from that of 'scene'. On the one hand, 'scene' refers to 'visual scenes...standard scenarios...institutional structures, enactive experiences... any kind of coherent segment of human beliefs, actions, experiences, or imaginations' . On the other hand, Frames are 'any system of linguistic choices'. People cognitively link scenes to frames; because scenes and frame 'activate' each other, Fillmore [11]. Importantly scenes do not change, however frames do. A scene is present in the physical world, people start associating it with different frames. Frames are dynamic and perspective by nature, unlike scenes. In other words, scenes refer to the worldly experience, while frames refer to the contextual language, Fillmore [12]. The two terms have been used alternatively.

Exploiting the semantic frames theory, the process of text understanding is analyzed as follows: the beginning of a text 'activates' a scene in the mind, but it leaves certain spaces unfilled, with the process going on, the spaces are filled, and new scenes are introduced. That is to say, the text initially summons a scene with the interpreter building some expectations, which can be fulfilled or refuted, by the end of the process a complete text-based experience is structured within a certain frame. Petrcuk[23] highlights that understanding a text depends on either 'word invocation' or 'interpreter evocation'. Explicitly mentioning the word 'birthday' invokes the birthday scene in the mind of the receiver. However, using the 'cake', 'candles' and 'presents', without plainly using the word 'birthday' leads the receiver to 'evoke' the birthday scene. In addition, the same birthday frame can be visually, non-linguistically, activated. The visual scene of wrapped presents, balloon decorated house, cake, and candles cognitively summons the birthday scene, without the need to any linguistic unit. Both language and perception play key role in the process of frame activation, Fillmore \& Baker[14].

\subsection{Barsalou's Model}

Barsalou [24] defines a frame as 'co-occurring set of abstract attributes, which take different values across 
category members', arguing for its dynamism and contextualization. The complex of related concepts in a frame entails a system of more specific linked concepts. The introduced model suggests three major elements forming any frame; attribute-value, structural invariants and constraints.

This model views the human knowledge as having two features: attribute-value sets and relations linking them. The frame is a system of conceptually related attributes and values. Being conceptually related, such attribute-value sets are cognitively perceived and stored together in the human mind (Figure 1). To demonstrate, the human cognitive knowledge of the attribute 'bird' stipulates the knowledge of its values; 'sing' and 'small'. It follows that the cognitive knowledge of 'sound' and 'size' attributes is activated too. Attributes are the broad concepts, superordinate, which contain a number of values, subordinates. Barsalou clarifies that core attributes of a frame are related in terms of frequency and conceptualization. They tend to co-occur frequently in the given contexts; because they are ideologically, regardless of the context, related. These fixed conceptual relations between frame attributes are referred to as 'structural invariants'. Unlike fixed structural invariants, values constraints are variably changeable. Constraints are the contextual relations combining values. They are specific and context dependent, such as the 'swimming' value which can situationally govern the occurrence of the 'sea' value. The provided frame constraints are inherently circumstantial. Barsalou [24] states that the attribute-value sets, structural invariants, and constraints embody the systematicity of any concept.

\subsection{National Anthems}

Al-Missiri [26] states that national anthems reflect certain ideologies based on the perception of the world. The reflected ideology is usually that of the ruling elite, which aims at getting people implement this ideology. Thus, a national anthem can either serve people or mislead them; depending on the ideology it represents. This political point of view argues that national anthems portray the self-other concept. They reveal how the country, its people (self) perceive themselves, and what they think of the other; being the enemy, other countries, or whatever entities. Linguistically speaking, national anthems usually use plain, simple, straightforward language. They intentionally avoid sophisticated metaphors.

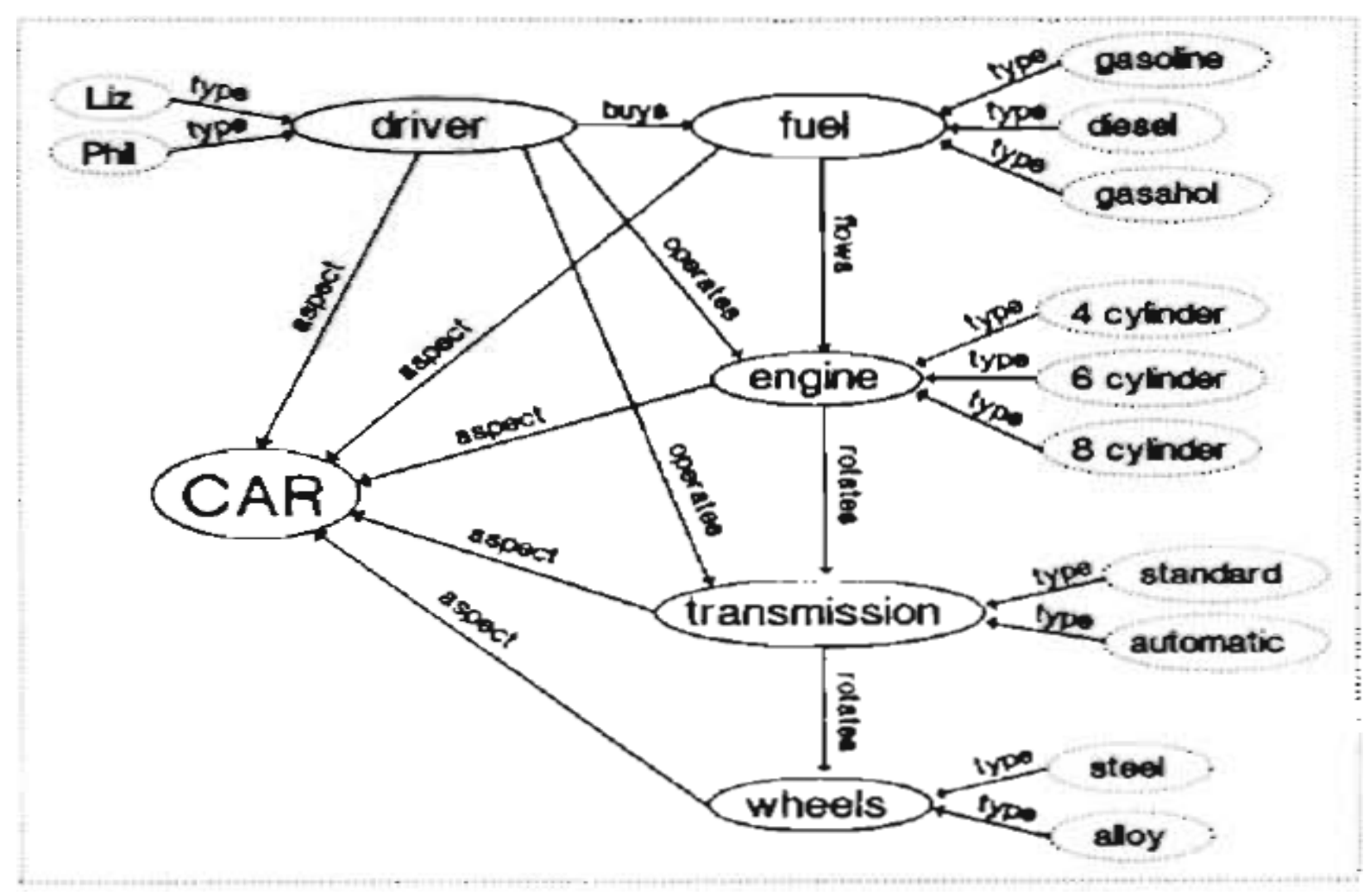

Figure 1. Barsalou's frame model of 'car' 


\subsubsection{English National Anthems}

England does not have an official national anthem, 'land of hope and glory', 'Jerusalem', and 'I vow to thee my country' are famous English national songs interchangeably used in official occasions. However, 'God save the queen', the national anthem of the United Kingdom, is the most frequent anthem sung in England during official occasions. According to the official website of the British monarchy[bb] 'God save the queen' used to be a famous patriotic song before it 'came to be known as' the national anthem of the United Kingdom in 1745. In other words, 'God save the queen' is not even officially declared to be the national anthem of UK, but it is conventionally referred to as such. Reported in the specialized national anthem website [17], 'Land of hope and glory' is written by Edward Elgar in 1902 to celebrate the coronation of King Edward VII. The song is locally popular in England and is associated with sport events. 'Jerusalem', written by William Blake, has become significant during the time of World War I. In 1922, King George V praised this patriotic song as more preferable than 'God save the queen'. The Independent Newspaper [27], David Cameron advocates the calls for an official national anthem for England, favoring 'Jerusalem' over any other patriotic song. 'I vow to thee my country', the national song of the British Indian Ocean Territory, is less frequent in England than other anthems, but still occasionally used. It has been advocated by Princess Diana, among others, to be the national anthem of England.

\subsubsection{Egyptian National Anthems}

The first Egyptian national anthem has been played during the reign of King A $\underline{h m a d}$ Fouad. At that time Egypt has been under the sovereignty of the United Kingdom. The anthem is totally devoted to the king, and is played along with the British anthem 'God save the queen'. The Egyptian anthem is an echo of the British one, Al-Missiri[26]. According to the Egyptian governmental official website[16], in 1923, after the United Kingdom has declared the independence of Egypt, Mostafa Saadeq Al-Rafe'ie's 'اسلمي بامصر/[Literary: be safe Egypt' becomes the new Egyptian national anthem. After the events of 1952, and the declaration of the Arabic Republic of Egypt, the national anthem changes to be Kamel A-Shennawi's 'نشيد الحرية'Literary: the anthem of freedom'. The Tripartite Aggression in 1956 marks another alteration of the national anthem. 'واله زمان يا سلاحي' [Literary:, written by the popular poet Salah Jahin, is set to be the national anthem, which is a reflection of the war state at that time. The last replacement of the national anthem is in 1979. 'بلادي/my homeland' has been the Egyptian national anthem hitherto. This anthem, composed by the poet Younis al-Qadi, is based on the opening lines of a political speech given by the leader Mustafa Kamel in 1907.

The substitution of the Egyptian national anthems corresponds to the political and historical salient developments throughout time.

\section{Discussion and Analysis}

\subsection{Analysis of English Data}

\subsubsection{A frame of 'God save the queen'}

Figure 2 represents the two major attributes of nationalism in 'God save the queen' as reflected in the title; God and queen. In other words, nationalism is defined in terms of power whether divine or royal. Moreover, the divine power is invariantly structured in terms of 'saving' the queen and 'scattering' her enemies. Very odd to the generic convection, there is no mention whatsoever to England. Comparing the value set of the queen to that of God substantiates, however, the superficial representation of the divine power and the overestimation of that of the ruler. It is illustrative of the 'ruler is God's representative' royal concept in England. Moreover, the values of 'God' and the values of the enemy constrain the occurrence of each other.

The working principles in this anthem are nobility, graciousness, and defense of laws, which are attributed, among other values, to the queen alone. According to 'God save the queen', the activated frame in the mind of the English by the nationalism concept would be inherently related to the ruler; king or queen, and being national equals praying for the queen, who is the sole always glorious defender of the country. The role attributed to citizens is implicitly praying for the queen and explicitly being [reign]ed over.

\subsubsection{Frame of 'Jerusalem'}

Figure 3 draws a nationalism picture of England, citizens and God. It is evident that England and citizens are the core attributes of the frame which are interlinked by the structure invariant 'build'. The conceptual nationalism relation between the English and England is, rationally, to 'build' it to look like the holy land of 'Jerusalem' -- a 'blessed' city by 'God'. The values, collocating with England, provide a striking contrast between what is hoped to be England and the real image of the country, highlighting the contradiction between the holy Jerusalem and England.

It is quite surprising to mention a country other than the homeland in the national anthem and shed the light on its holier position. However, it is sincere in pinning citizens' national range of aspirations and hopes for their country. Citizens, as a core attribute of the frame, are accordingly associated with a powerful set of values 'sword', 'arrow', and 'spear', which are needed to go through the 'mental fight' of converting England with its 'cloud...dark satanic hills' into a holy 'Jerusalem'.

There is no governing principle in the anthem, save for the 'hope' to 'build'. All the values associated with 'God' are conceptually linked to some of 'England' values, crystallizing the national hope of the citizens. 


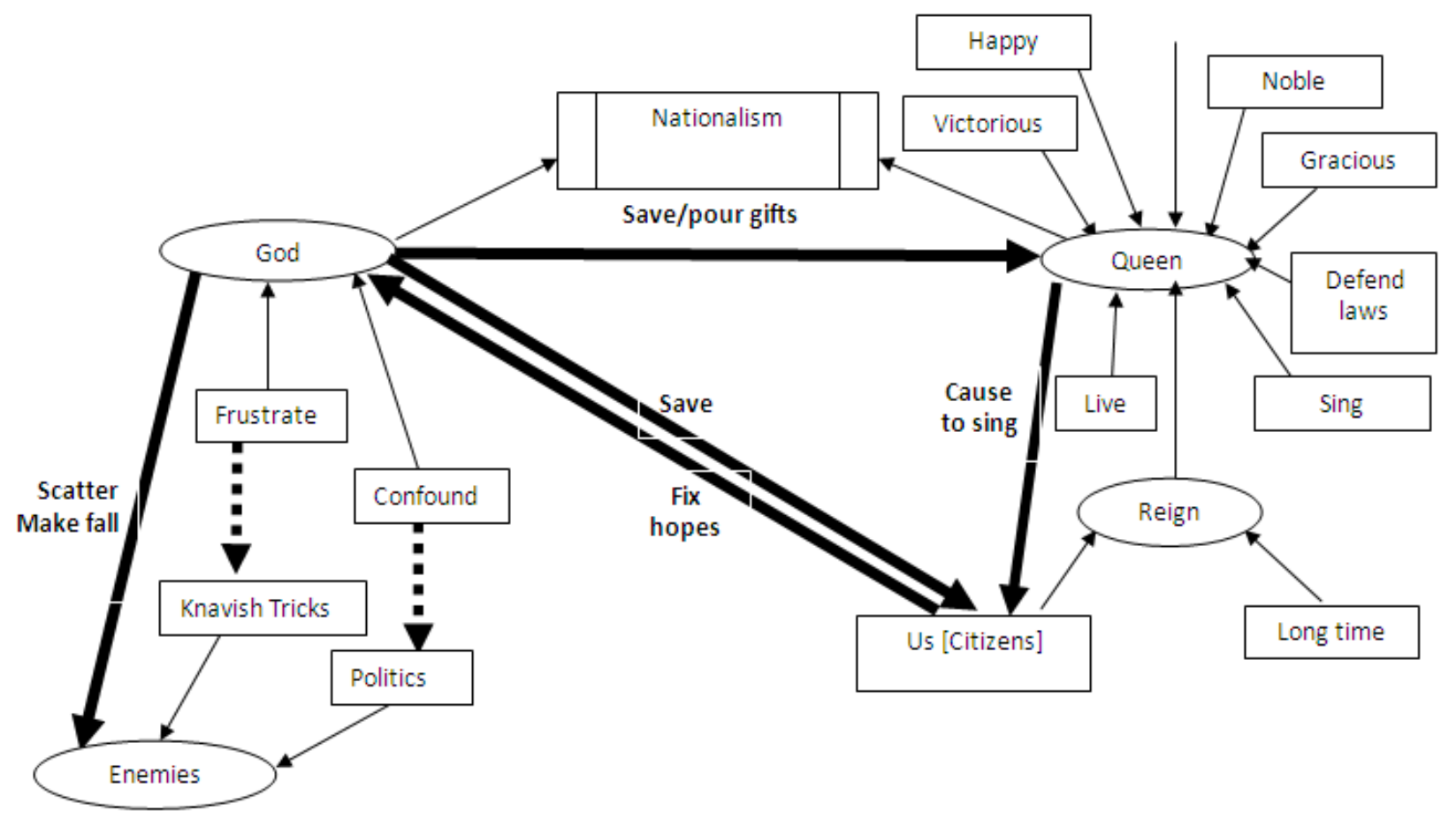

Figure 2. A Frame of the English National anthem 'God save the queen'

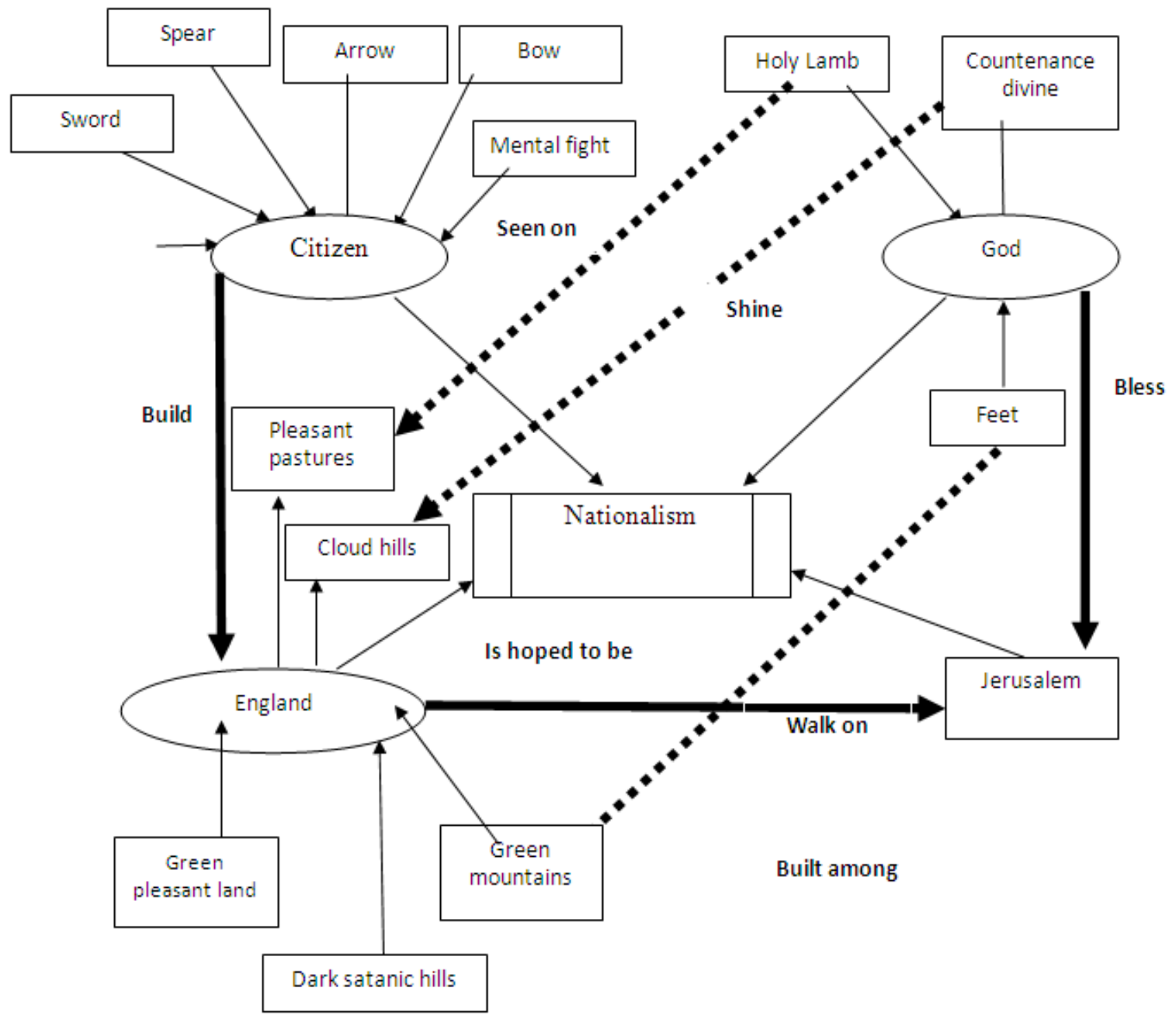

Figure 3. A frame of the English national anthem 'Jerusalem' 


\subsubsection{Frame of 'I vow to thee my country'}

According to figure 4, 'I vow to thee my country' activates the 'citizens love and serve country' frame. The basic attributes of nationalism are country (homeland), citizens, love, battle, and interestingly another country; heaven as suggested by critics.

Figure 4, providing the value sets of the four attributes, projects the importance to the homeland country more than to citizens, and to the other country more than the homeland country. The battle values are shared with the homeland county, another country, and even with love, but not with citizen. The mentioned 'another country' is believed to be heaven; the original homeland of mankind. That is why; the values associated with it are richer and more effective.

The defending principle is highly summoned in this frame as well as the love principle. The concept of power is distributed between 'battle', 'country', 'another country' and 'love', but it leads to the same conclusion 'power' to 'defend' or 'sacrifice' for the country.

Love is explicitly stated and attributed within the frame, while defense is inferred from the battle aspect and its values. The structural invariant that constrains the country-love relation is 'vow[ing]' to 'love' and 'serve'. Although ' $I$ ' is frequently enrolled in the anthem, citizen, as a value of nationalism, is marginalized, if compared to attributes of country, love or battle.

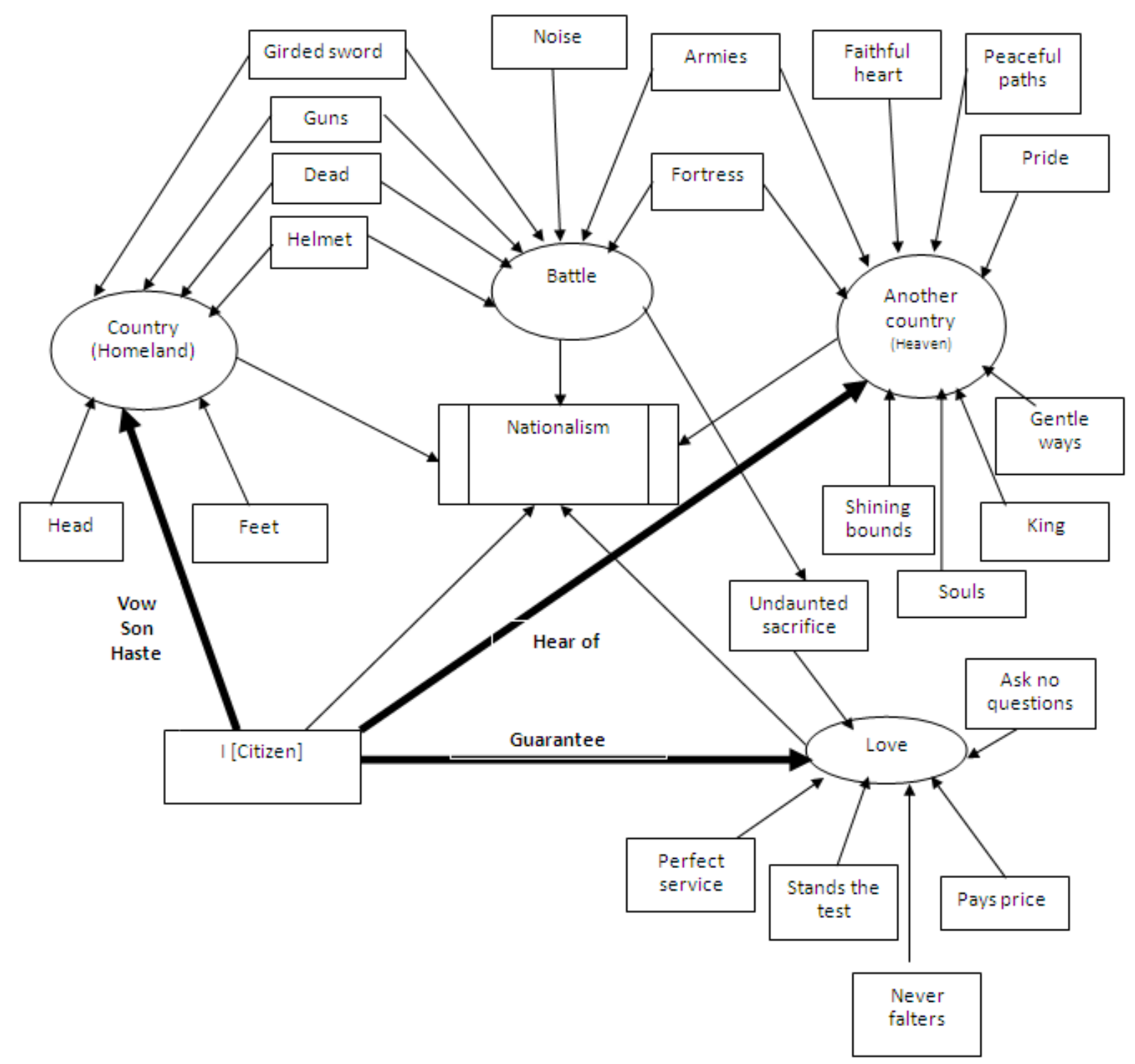

Figure 4. Frame of English the national anthem 'I vow to thee my country' 


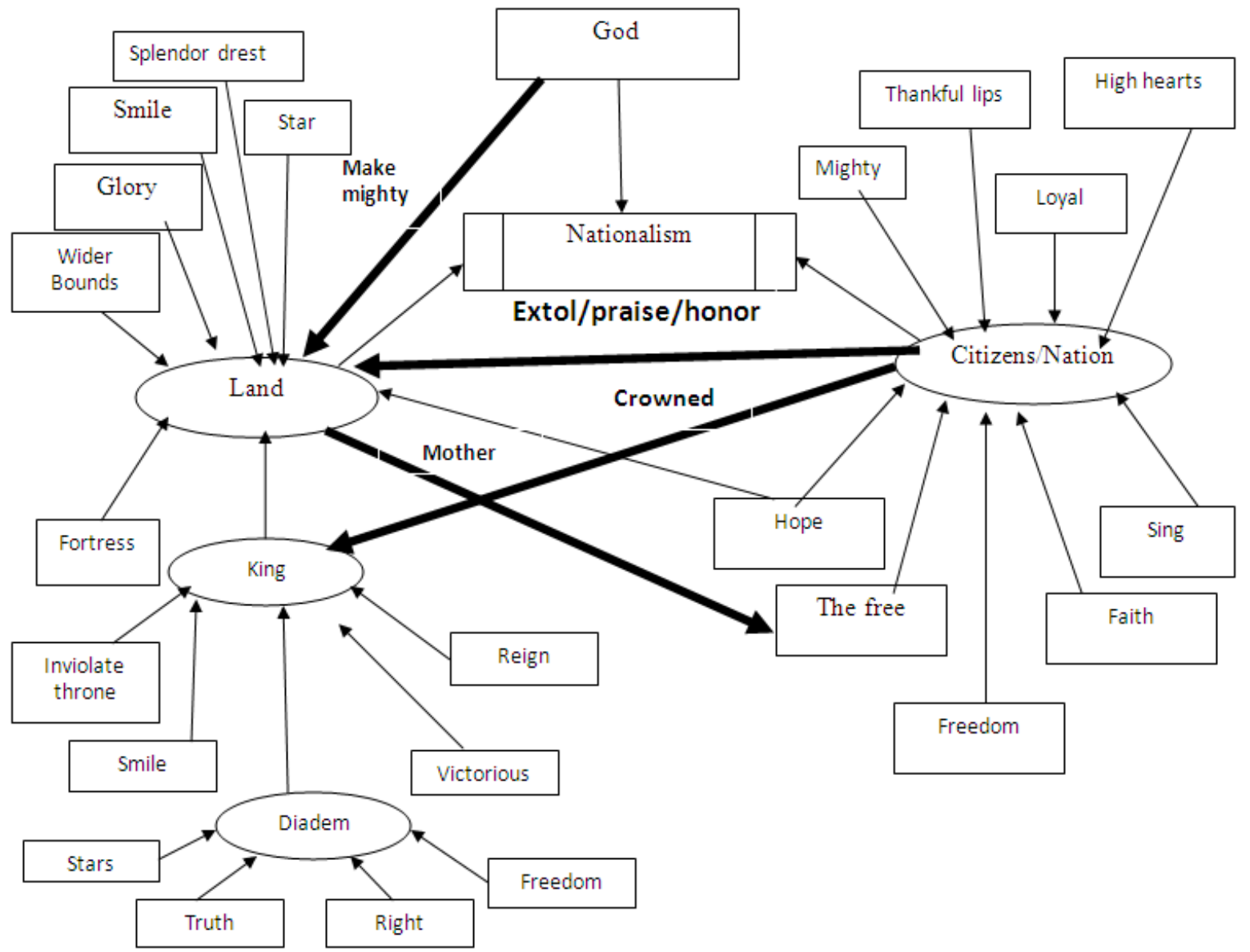

Figure 5. A frame of the English national anthem 'Land of hope and glory'

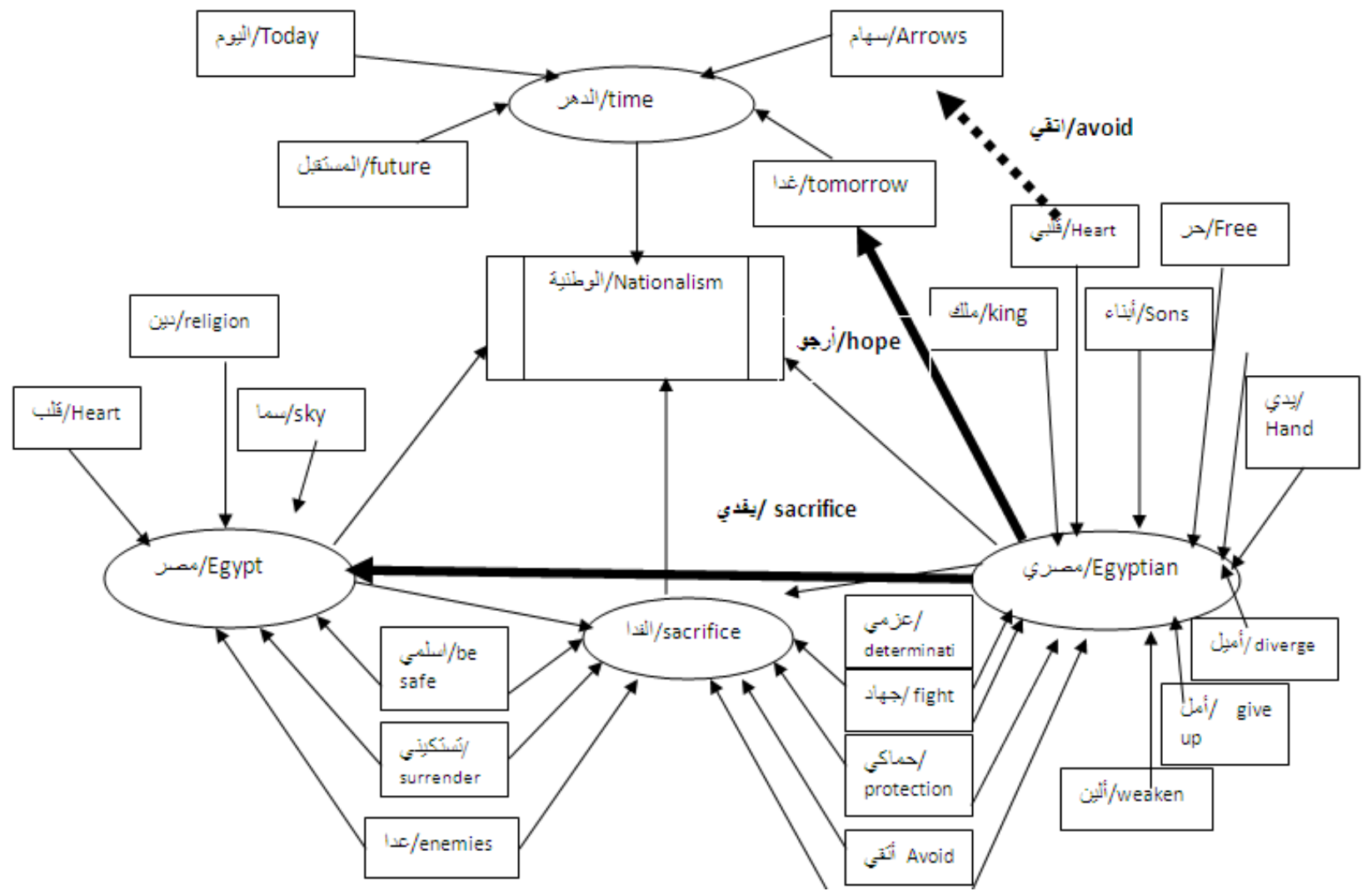

Figure 6. A frame of the Egyptian national anthem ' اسلمي يا مصر, 


\subsubsection{Frame of 'Land of hope and glory'}

Nationalism frame in 'Land of hope and glory' is country-citizen centered. The fixed conceptual relation between them is to 'extol'. The divine power is partly mentioned as the primer of making the land 'mighty'. The ruler power is strongly invoked in a number of royal values; 'throne', 'reign', 'diadem'. The ruler-citizen correlation is expressed in 'crowned', which places citizens in the doer position.

The principles of 'hope', 'freedom', 'loyalty', 'truth', and 'right' are recurrent and correlate with both the country and its citizens. These shared values between the two major attributes imply the very concept that an ideal citizen is born of his/her ideal country. The anthem depicts nationalism as a citizen who extols his country: a conventional dramatic narrative which represents hope and glory.

Classical to what is initially activated in the mind, place is the starting point of the frame. It summons a number of values 'glory', 'strong', 'hope', and 'freedom', and recalls the ideal citizen image who is always 'thankful', 'loyal', faithful' to his 'mother' country. Country is, then, an inspiration towards perfection.

\subsection{Analysis of Arabic Data}

\subsubsection{Frame of ' اسلمي يا مصر/be safe Egypt'}

The frame of 'اسلمي يا مصري'/be safe Egypt' presents 'مصري/Egyptian', 'الفدا/sacrifice', and 'مصلي 'Egypt' as the key aspects of nationalism. 'الفدا/sacrifice' is the most essential element in the frame; as it is introduced as an attribute and structural invariant links the other two attributes; 'مصر/Egypt' and 'مصري/Egyptian'. Moreover, the set of values associated with 'الفري/:sacrifice' are shared with the major attributes; 'مصر/Egypt' and

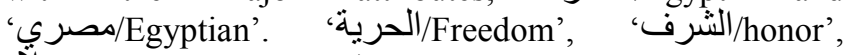

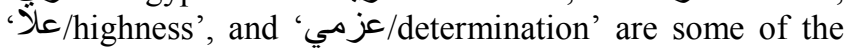
principles shared by the Egyptians. Power is reflected in the values of 'الفدا sacrifice' which refers to the power of citizens against the power of enemy to defend the country. That is to say, nationalism cognitively activates the frame of 'الفدا/sacrifice', with all its stipulated frames, but sacrifice is the starting point triggered in the mind.

The divine power is mentioned in the frame, but metaphorically, 'أنت بعد الدين دين (Egypt is a second religion). Country is promoted to a highly sacred level that is comparable to the highness of a religion. Such a depiction crystallizes the strength of nationalism ties. The ultimate goal of nationalism is country safety secured by its people. The frame's richness emerges from the number of its shared values among the attributes, which are alternatives to the conceptual relations among attributes and the constraints of values.

\subsubsection{Fame of 'نشيد الحرية/ Freedom anthem’}

Figure 7 marks the complex development in the nationalism frame pertaining to the number of values, attributes, and the conceptual relations between them. The freedom-restriction dualism and avenge to attain justice are as essential attributes as Egypt and Egyptians to the frame. Nationalism is no longer defined in terms of defense and sacrifice; it is basically restoring the freedom of the country, whatever it takes.

The image of injustice, martyrs and blood are highlighted in the values and the structural invariants. Martyrs-Egyptians correlation is structured as أبي"/my father, ولدي/my son, أخي/my brother, أمي/my mother, أختي أخ sister'. The fixed conceptual relation between the activated frame of 'ثناري/revenge' and that of 'حرية/freedom' is 'بسترد/restore'.

The comparison between the two attributes 'قيود/2restrictions' and 'freedom/حرية' spontaneously activates the frame of 'revenge'. Moreover, the structural invariant of 'tyranny/ظل between Egypt and the oppressor with values such as 'pain/تألم/تو' , 'suppression', ' conceptually correlate to 'revenge'. The five attributes of the frame alternatively summon each other; Egyptians avenge to destroy restrictions and restore the freedom of Egypt.

\subsubsection{Frame of "الله زمان يا سلاحي/}

Figure 8 introduces a new attribute to the nationalism frame; 'war'.

For the first time, war is not implied in terms of defense or valued in the attribute of sacrifice. It stands, however, as a foundation attribute in the frame. Moreover, the association between people and weapon is fixedly structured in 'رفيق/companion'.

The values of 'نصفر/victory' and 'جنود/soldiers' confine each other, victory is exclusively achieved by soldiers. People also collocate with enemy in terms of killing and with Egypt in terms of defense and glory. The governing structural invariant of people and country attributes is the typical defense. The emergence of war attribute stipulates all power values, and raises the position of the army to a much higher extent so that one of the fixed relations in the frame is associated with soldiers, and another collocates with weapon. The values of people attribute clarify that people are cognitively seen as part of the army, not vice versa. That is to say, in time of war people and the army are soldiered. 


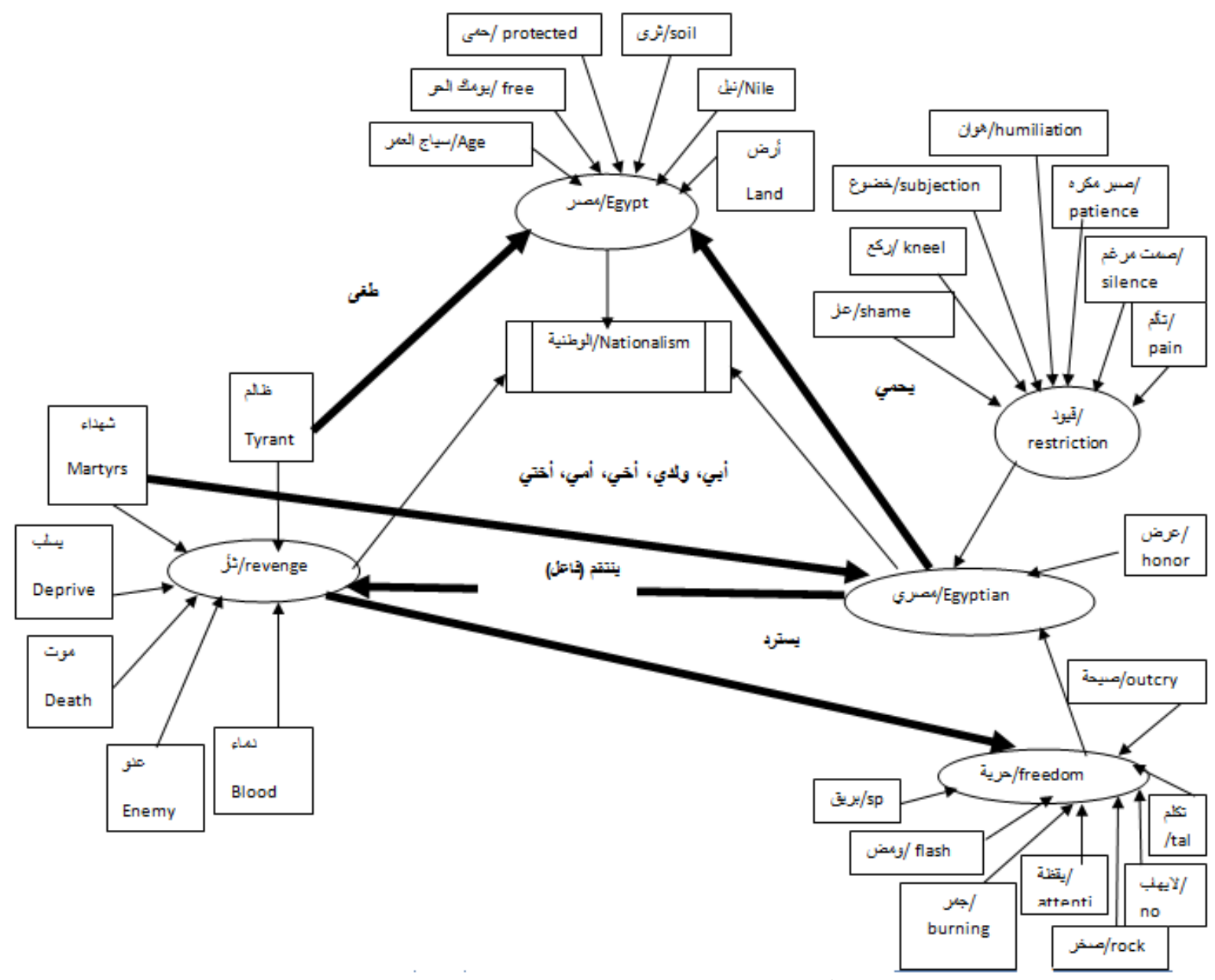

Figure 7. A frame of the Egyptian national anthem نشيد الحرية،

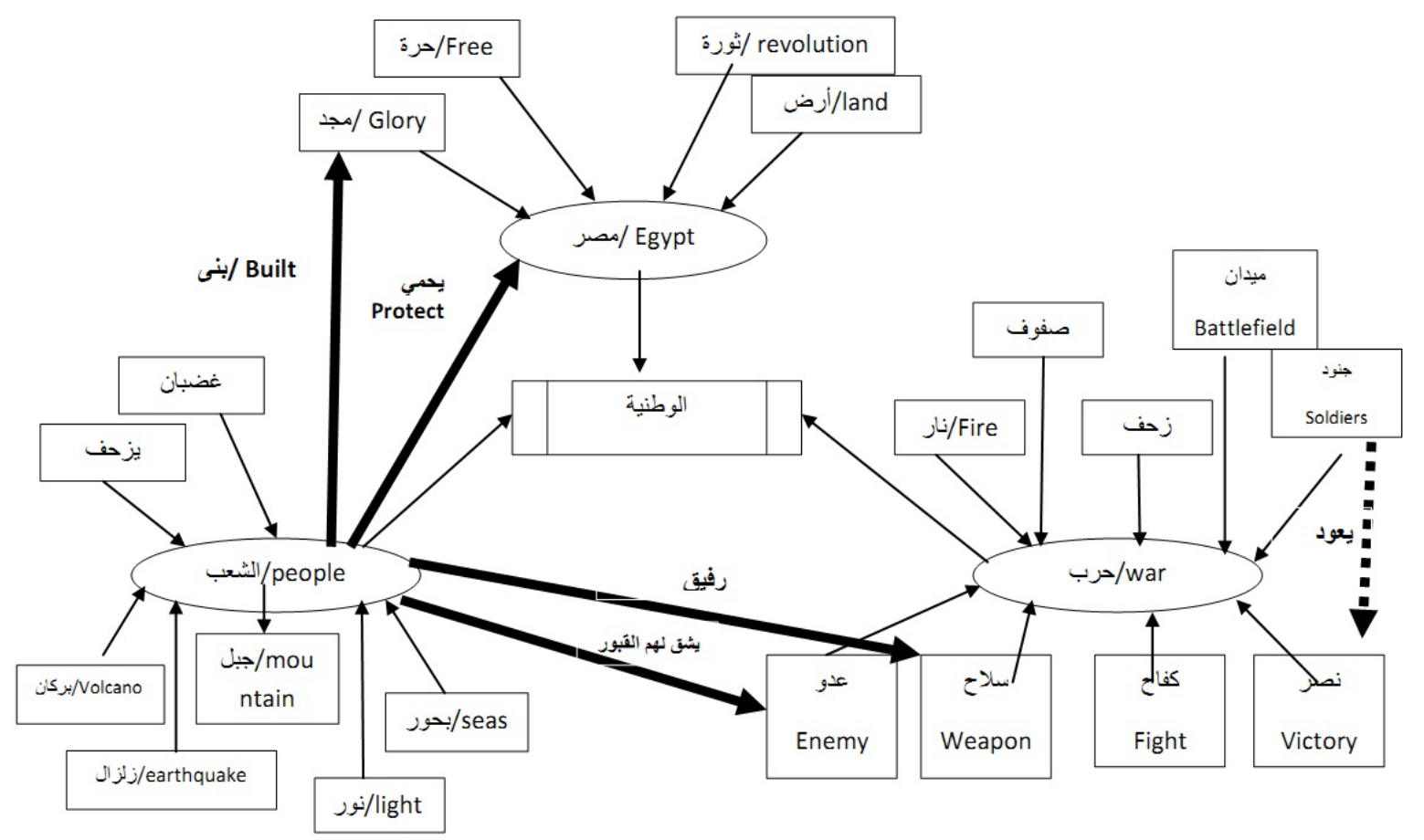

Figure 8. A frame of the Egyptian national anthem 'و اله زمان باسلاحي' 


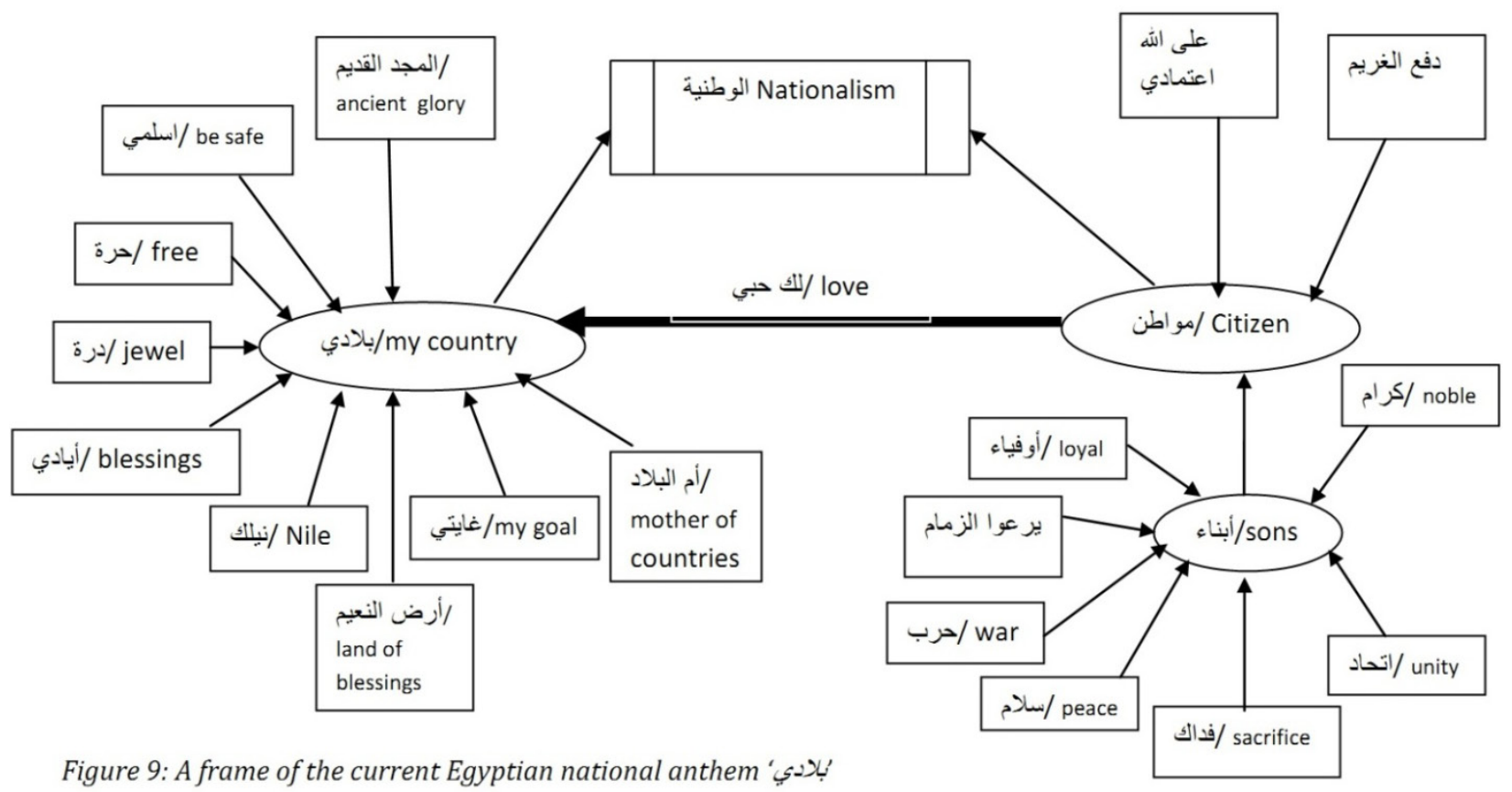

Figure 9. draws a frame of the current Egyptian national anthem. It reflects the stable national state of security, in which only 'love' is a default definition of nationalism.

Table 1. Frequency of attributes/values in each frame

\begin{tabular}{|c|c|c|}
\hline National Anthem & Attributes & Values \\
\hline \multirow{5}{*}{ God save the queen } & 4 & 15 \\
\hline & God & 2 \\
\hline & Queen & 9 \\
\hline & Reign & 2 \\
\hline & Enemy & 2 \\
\hline \multirow{4}{*}{ Jerusalem } & 3 & 15 \\
\hline & Citizens (I) & 6 \\
\hline & England & 5 \\
\hline & God & 4 \\
\hline \multirow{5}{*}{ I vow to thee my country } & 4 & 29 \\
\hline & Country (homeland) & 6 \\
\hline & Another country (Heaven) & 9 \\
\hline & Battle & 8 \\
\hline & Love & 6 \\
\hline \multirow{5}{*}{ Land of hope and glory } & 4 & 26 \\
\hline & Land & 8 \\
\hline & Citizens (We) & 9 \\
\hline & King & 5 \\
\hline & Diadem & 4 \\
\hline \multirow{5}{*}{$\begin{array}{l}\text { / اسلمي يا مصر } \\
\text { /be safe Egypt }\end{array}$} & 4 & 34 \\
\hline & مصر/Egypt & 6 \\
\hline & /الفدا/Sacrifice & 10 \\
\hline & & 14 \\
\hline & الدهر/Time & 4 \\
\hline \multirow{6}{*}{$\begin{array}{c}\text { نشيد الحرية } \\
\text { /Freedom anthem }\end{array}$} & 5 & 30 \\
\hline & صصر/Egypt & 6 \\
\hline & ثأر/Revenge & 6 \\
\hline & |Egyptian & 3 \\
\hline & & 7 \\
\hline & & 8 \\
\hline \multirow{4}{*}{ و والله زمان يا سلاحي } & 3 & 20 \\
\hline & الشعب /people & 7 \\
\hline & مصر/Egypt & 4 \\
\hline & حرب/war & 9 \\
\hline \multirow{4}{*}{ بلادي/My country/ب } & 3 & 19 \\
\hline & البلادي/My country & 9 \\
\hline & 年/Egyptian & 3 \\
\hline & أبناء/Sons & 7 \\
\hline
\end{tabular}




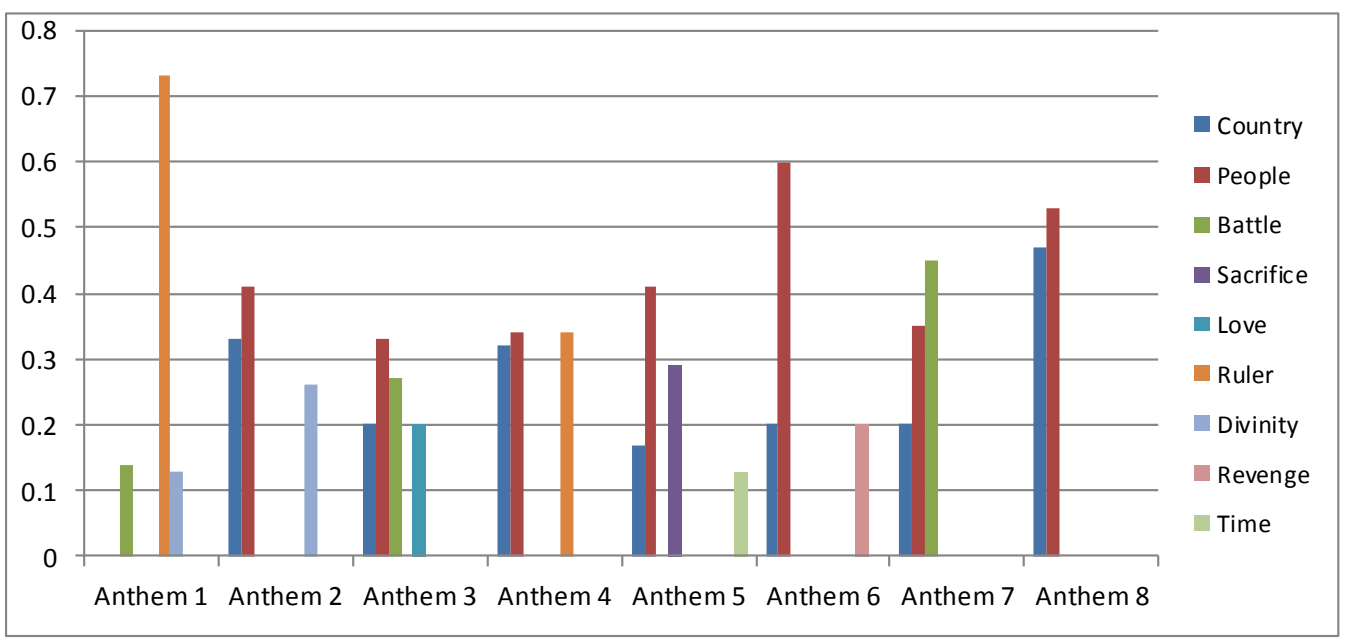

Figure 10. The distribution of attributes in the eight anthems

\subsubsection{Frame of 'بلادي/ my county'}

'Defense', 'freedom' and 'sacrifice' are all represented, but as values, among many others, neither as major attributes nor structural invariants. The country-citizen dualism turns to be the sole attribute in the frame and structured by means of love. According to the used values in the frame; 'freedom', 'nobility', 'loyalty', 'glory', and 'unity', the frame is principle-based. The divine power is present in one value of the citizen's attribute. It is introduced as the main power upon which citizens depend to serve and protect the country. 'وعلى الله اعتمادي' [literally: On Allah, I rely] reflects the deep national faith in the divine power to reach the patriotic aims of defending the country and rebelling enemies. The divine power and the national power are combined together promoting the divine over the national and directing both against the enemy.

\section{Findings and Results}

\subsection{Frequency of Attributes/Values in Frames}

Each of the eight frames is a reflection of a relatively different scene. The English ones reflect the monarchy concepts and the long shared belief of royal power representing divine power, which is regularly represented in the four anthems. They also reflect the native's sense of homeland's superiority and the readiness to military serving it at any time. This reflects the past glorious history of the British Empire. One of them, Jerusalem, reflects the romantic frustration with the fallen reality of England then, and the sincere hopes of establishing a divine England. The Egyptian national anthems, however, have no mention whatsoever to the ruler. They typically depend on the power of people to defend the country. They project the different realities of the progressive Egyptian scenes; being occupied, revolving, being military attacked, and being military victorious.

Some frames place country or people at the heart, while others celebrate the role of sacrifice as the sole exposition of nationalism. The current table provides the distribution of attributes/values in each frame.

\subsection{Distribution of Core Attributes in the Eight Anthems}

This bar chart illustrates that country and people are the core shared attributes typically shared almost by the eight anthems. It also reveals that the divine and the ruler power are common among the English anthems, while absent in the Egyptian ones. Anthems 3 and 7 summon the same conceptual frames; country, people and battle, but anthem 3 additionally activates the concept of love. The presence of sacrifice and revenge as core attributes in the Egyptian national anthems, unlike the English ones, reflects the occupation, war, and revolution events the Egyptians have been through since 1923; the date of the first official national anthem. It is also reflected in the attribute of time; introduced as a mysterious power likely to bring about more challenges.

\subsection{Statistical Findings}

Based on the pervious frames, Principles, Power, Place, and People are the core attributes of NATIONALISM. Two statistical tests are applied to check the relation among the four attributes on the one hand, and between them and the other constituents of the frames on the other hand. By applying the Chi-square tests for association between two categorical variables, the results read as follows: 


\begin{tabular}{cccccccccccc}
\hline & Principles & \multicolumn{2}{c}{ People } & \multicolumn{2}{c}{ Power } & \multicolumn{2}{c}{ Place } & \multicolumn{2}{c}{ Others } & \multicolumn{2}{c}{ Row Totals } \\
\hline The anthems of England & 16 & {$[3.77]$} & 25 & {$[1.86]$} & 24 & {$[1.65]$} & 33 & {$[0.29]$} & 36 & {$[3.16]$} & 134 \\
\hline The anthems of Egypt & 40 & {$[3.24]$} & 46 & {$[1.60]$} & 16 & {$[1.41]$} & 32 & {$[0.25]$} & 22 & {$[2.71]$} & 156 \\
\hline Marginal Column Totals & \multirow{2}{*}{56} & \multicolumn{2}{c}{71} & \multirow{2}{*}{40} & \multirow{2}{*}{65} & \multirow{2}{*}{58} & $\begin{array}{r}290 \\
\text { (Grand } \\
\text { Total) }\end{array}$ \\
\hline
\end{tabular}

The obtained chi-square value is 19.9375 . The P-Value is 0.000514 . The result is significant at $p<0.05$. It means that there is a significant correlation between the prominences of the four attributes themes in relation to the other themes in the studied eight anthems.

Moreover, this paper used Pearson correlation coefficient (R), which measures the strength and direction of the relationship between two variables, to investigate the categorical relation in the way of using these constitutional attributes in the anthems of England and Egypt respectively. The value of $\mathrm{R}$ is -0.2399 ; i.e., reciprocal weak correlation. To simplify, it means that the usage of the four attributes in the anthems of England and Egypt is heterogeneous; anti-directional and reciprocal. In sociolinguistic terms, it proves that the oriental and occidental influence affected the prioritization of the microstructural elements.

\section{Conclusions}

To conclude, the eight national anthems represent different scenes; glorifying the ruler, love for a country, defense, hope, freedom restoration, loyalty and serving in war and peace. Some frames are similar in their attributes, values, or structural invariants, while others are similar in summoning a certain concept, but structuring it differently in the frame. In other word, the shared item can be activated as central attribute of the frame or as s peripheral value of an attribute. These variant perspectives of the same item reflect the different political and cultural scenes in each county, and crystallize the native cognition about country according to the physical experience.

NATIONALISM, as framed in the eight national anthems, activates four major attributes; People, Place, Power and Principles. These four attributes exhibit high degree of variability in their values; Power and Principles in particular. Power as a variable can invoke the divine power, the power of the ruler, army, law, or citizens. Principles governing people extremely vary according to the anthem; sacrifice, love, unity, or even glorifying the ruler as God's representative. Place is typically the homeland, but some other country can be rarely mentioned too. However, the number of values collocating with the homeland crystallizes the centrality of the homeland. Moreover, outstanding places and monuments mentioned, hence activated in the mind, are parts of the homeland. NATIONALISM typically summons the frame of people sharing a number of principles living in the same place and constrained by the same power.

\section{CONVERGING EVIDENCE}

The suggested frame of NATIONALISM is deeply rooted in sociology. Ibn Khaldūn, setting the bases of this new science, divides nations according to the territory they live in. He argues that humans are sociable by nature. Whenever people are gathered in one place, they tend to work together to attain security and fulfill the human basic needs, in other words to survive. So, they cooperate to defend the place they live in and are united against any potential risk. Moreover, any community, society; group of people living in the same place and working to achieve common goals, are typically governed by a certain authority. Sociology argues that power distribution of groups can vary across time, so do the space they live in and their shared goals. However, the four elements are present in any nation at any time.

NATIONALISM is cognitively structured as people, place, principles and power, which are the typical foundations of human sociology. The four basic attributes take different forms in different contexts. People develop their governing principles across time and place starting from cooperation to survive and realize basic needs, to loving country, to defend for it, or achieving its independence. Authority, which is represented in the frame as power, varies according to time, place and people. The ruling power can be government, religious authority, traditions, laws, or whatever power presiding over people and constraining their actions.

\section{Recommendations}

Further linguistic research in this area may choose to apply the suggested conceptual frame on a larger scope of national anthem to measure its validity. Modern theories of nations and nationalism should be revisited and reviewed for a more comprehensive paralinguistic measure, emanating from the results of the research analysis and the suggested frame. 


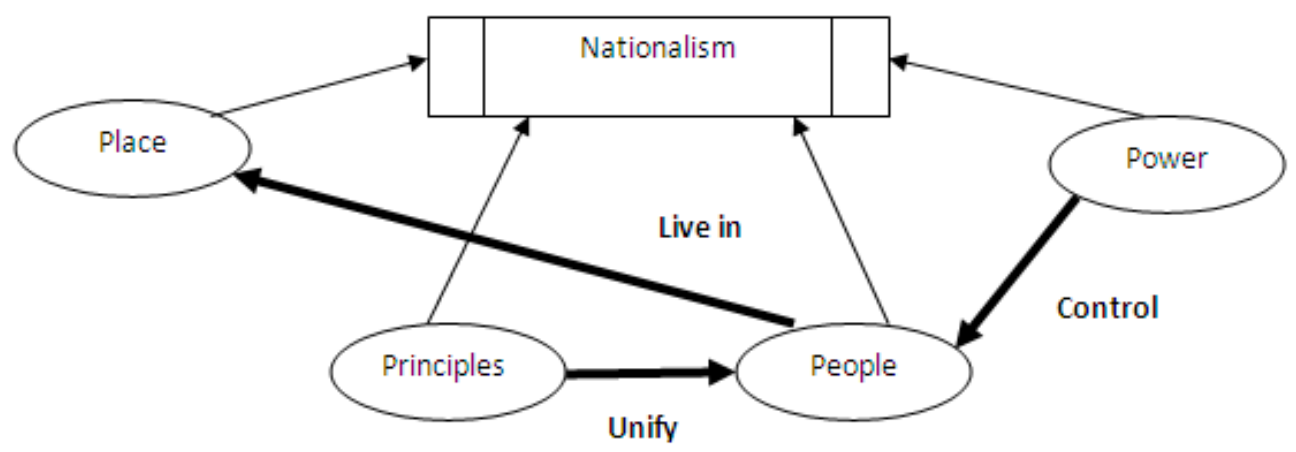

Figure 11. A suggested cognitive frame of nationalism

\section{List of Symbols}

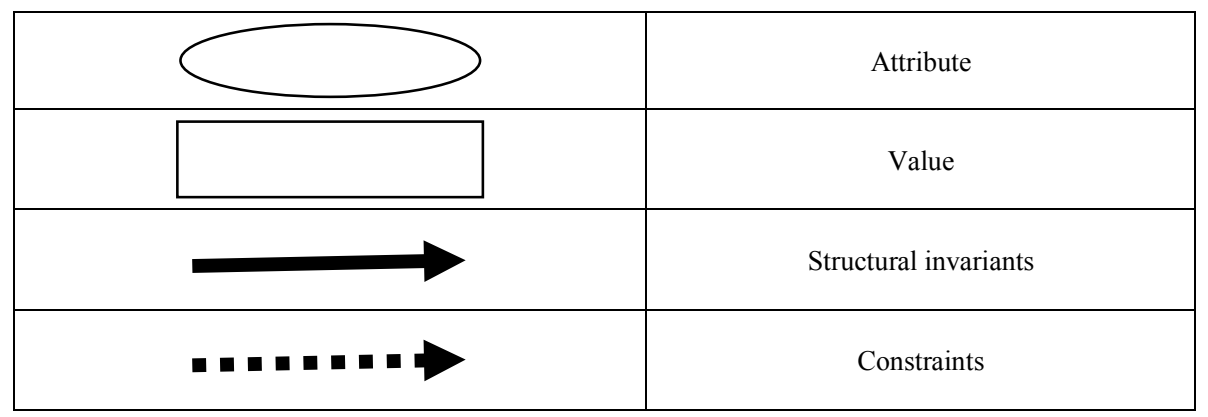

\section{REFERENCES}

[1] Gellner, E. (1983). Nations and Nationalism. Ithaca: Cornell University Press. 6-7.

[2] Anderson, B. (1991). Imagined Communities: Reflections on the Origin and Spread of Nationalism. Revised Edition ed. London and New York: Verso.

[3] Smith, A. (1991). National Identity. Reno: University of Nevada Press.

[4] Online available from http://www.merriam-webster.com/

[5] Richards, J. \& Schmidt, R. (2010): Longman Dictionary of language Teaching and Applied Linguistics. $4^{\text {th }}$ Edition. Edinburgh: Pearson

[6] Online available from http://www.oxforddictionaries.com/

[7] Online available from http://www.baheth.info/

[8] Billig, M (1993). Studying nationalism as an everyday ideology. Papers on Social Representations (PSR), 2. Online.

[9] Evans, V. \& Green, M. (2006). Cognitive linguistics: An Introduction. Edinburgh: Edinburgh University Press

[10] Fillmore, C. (1975) 'An alternative to checklist theories of meaning', Proceedings of the First Annual Meeting of the Berkeley Linguistics Society. Amsterdam: North Holland, 123-31

[11] Fillmore, C. (1977). Scenes-and-frames semantics, in Zampolli, A. (ed.), Linguistic Structures Processing. Amsterdam: North Holland, 55-82
[12] Fillmore, C. \& Atkins, B. (1992). Toward a frame-based lexicon: the semantics of RISK and its neighbors'. In Lehrer, A. \& Kittay, E. (eds). Frames, Fields and Contrasts. New Jersey: Lawrence Erlbaum. 75-102

[13] Petruck, M (1995). Frame semantics and the lexicon: nouns and verbs in the body frame. In Essays in Semantics and Pragmatics: In Honor of Charles J. Fillmore. Shibatani, M. \& Thompson, S. (eds). John Benjamins compan

[14] Fillmore, C. \& Baker, C. (2009). A frames approach to semantic analysis. In Heine, B. \& Narrog, H. (eds), The Oxford Handbook of Linguistic Analysis. Oxford: Oxford University Press

[15] Xie, B., Passonneau, R., Wu, L. \& Creamer, G. (2013). Semantic Frames to Predict Stock Price Movement. Proceedings of the 51st Annual Meeting of the Association for Computational Linguistics. Sofia: Association for Computational Linguistics.

[16] Lo, C., \& Wu, D. (2011). MEANT: An inexpensive, high-accuracy, semi-automatic metric for evaluating translation utility via semantic frames. Proceedings of the 49th Annual Meeting of the Association for Computational Linguistics(ACL). Oregon: the ACL.

[17] Online available from http://www.nationalanthems.info/

[18] Online available from http://www.sis.gov.eg/Ar/Templates/Categories/tmpLand.as $\mathrm{px}$ ? CatID $=10$

[19] Online available from http://www.royal.gov.uk/MonarchUK/Symbols/NationalAnt hem.aspx

[20] Evans, V. (2007). A glossary of cognitive linguistics. Edinburgh: Edinburgh University Press. 
[21] Fillmore, C. (2006). Frame semantics. In Geeraerts, D. (Cognitive linguistics: basic readings). Berlin: Gruyter.

[22] Richards, j. \& Schmidt, R. (2010): Longman Dictionary of language Teaching and Applied Linguistics. 4th Edition. Edinburgh: Pearson

[23] Petruck, M.( 1996). Frame semantics. In: Verschueren, J. et al. (Ed.). Handbook of pragmatics. Philadelphia: John Benjamins.

[24] Barsalou, L. (1993). Flexibility, structures, and linguistic vagary in concepts: Manifestations of a compositional system of perceptual symbols. In Collins, A., Gathercole, S., Conway, M. \& Morris, P. (eds.), Theories of Memory. New Jersey:

\section{Lawrence Erlbaum}

[25] Barsalou, L. (1993). Flexibility, structures, and linguistic vagary in concepts: Manifestations of a compositional system of perceptual symbols. In Collins, A., Gathercole, S., Conway, M. \& Morris, P. (eds.), Theories of Memory. New Jersey: Lawrence Erlbaum

[26] Al-Missiri, A. (2007). Studies in poetry. Cairo: Al-Shrouk International Library.

[27] Online available from http://www.independent.co.uk/news/uk/politics/cameron-wo uld-choose-jerusalem-as-national-anthem-for-englands-sport s-teams-7945250.html 